\title{
Advances in Enteric Neurobiology: The "Brain" in the Gut in Health and Disease
}

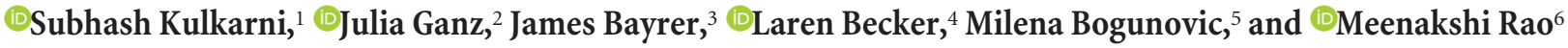 \\ ${ }^{1}$ Department of Medicine, The John Hopkins University School of Medicine, Baltimore, Maryland 21205, 2Department of Integrative Biology, Michigan \\ State University, East Lansing, Michigan 48824, ${ }^{3}$ Department of Pediatrics, University of California, San Francisco, San Francisco, California 94143 , \\ ${ }^{4}$ Department of Medicine, Stanford University, Stanford, California 94305, ${ }^{5}$ Department of Microbiology and Immunology, Penn State College of Medicine, \\ Hershey, Pennsylvania 17033, and 'Division of Gastroenterology, Boston Children's Hospital and Harvard Medical School, Boston, Massachusetts 02115
}

The enteric nervous system (ENS) is a large, complex division of the peripheral nervous system that regulates many digestive, immune, hormonal, and metabolic functions. Recent advances have elucidated the dynamic nature of the mature ENS, as well as the complex, bidirectional interactions among enteric neurons, glia, and the many other cell types that are important for mediating gut behaviors. Here, we provide an overview of ENS development and maintenance, and focus on the latest insights gained from the use of novel model systems and live-imaging techniques. We discuss major advances in the understanding of enteric glia, and the functional interactions among enteric neurons, glia, and enteroendocrine cells, a large class of sensory epithelial cells. We conclude by highlighting recent work on muscularis macrophages, a group of immune cells that closely interact with the ENS in the gut wall, and the importance of neurological-immune system communication in digestive health and disease.

\section{Introduction}

The gut is the largest microbial, endocrine, and immune organ in both humans and mice. It contains its own intrinsic enteric nervous system (ENS) that regulates a variety of gastrointestinal functions and communicates bidirectionally with the CNS and extraenteric peripheral nervous system. The ENS is derived from neural crest progenitors that colonize the gut during fetal development to form two interconnected ganglionated plexuses that wrap around and integrate into the laminar structure of the digestive tract (Fig. 1). The myenteric plexus, which is the larger of the two plexuses, is located between two layers of smooth muscle and extends throughout the digestive tract. The submucosal plexus is located in the submucosa, closer to the intestinal lumen, and extends from the stomach through the rectum. There are estimated to be 100 million neurons in the human small intestine alone, making the ENS the largest collection of neurons and glia outside the brain, and by far the largest division of the peripheral nervous system (Furness, 2006). The ENS contains a diversity of neurons and glia (Zeisel et al., 2018), and virtually every CNS neurotransmitter is also found in the ENS (Furness, 2006). Nev-

Received July 31, 2018; revised Sept. 20, 2018; accepted Sept. 22, 2018.

S.K. was supported by Department of Health and Human Services (DHHS)/National Institutes of Health (NIH)/ National Institute of Diabetes and Digestive and Kidney Diseases (NIDDK) Grant P30-DK-089502; J.G. was supported by a Research Award from the American Neurogastroenterology and Motility Society. M.B. was supported by DHHS/ NIH/National Institute of Allergy and Infectious Diseases Grant R21-Al-126351 and an Innovation Award from the Kenneth Rainin Foundation. M.R. was supported by DHHS/NIH/NIDDK Grant K08-DK-110532.

The authors declare no competing financial interests.

Correspondence should be addressed to either of the following: Subhash Kulkarni, Department of Medicine, The John Hopkins University School of Medicine, Baltimore, Maryland 21205, E-mail: skulkar9@jhmi.edu; or Meenakshi Rao, Division of Gastroenterology, Boston Children's Hospital and Harvard Medical School, Boston, Massachusetts 02115, E-mail: Meenakshi.Rao@childrens.harvard.edu.

DOI:10.1523/JNEUROSCI.1663-18.2018

Copyright $\odot 2018$ the authors $\quad 0270-6474 / 18 / 389346-09 \$ 15.00 / 0$ ertheless, the full extent of enteric neuronal heterogeneity and circuitry remain incompletely understood. The ENS exhibits a columnar topology along the radial axis of the gut (Lasrado et al., 2017), similar to the CNS; however, the logic underlying why certain enteric neurons are grouped into ganglia is largely unclear.

Recent advances using new model systems and genetic tools are dramatically changing the understanding of ENS development. A thorough description of ENS development is beyond the scope of this review but has been covered previously (Lake and Heuckeroth, 2013; Rao and Gershon, 2018). Here we focus on reviewing the latest work, particularly how the zebrafish model system has been leveraged to understand links between the CNS and ENS in human neurodevelopment. We also address how genetic lineage tracing and in vivo imaging approaches in mice have demonstrated unprecedented levels of adult enteric neurogenesis that are required to maintain ENS homeostasis in the face of continual neuronal loss. These models and tools have allowed us to understand novel cellular and molecular mechanisms by which the ENS is formed and maintained, thereby giving us a new understanding of the regulation of gastrointestinal functions. New genetic tools and approaches have also uncovered surprising roles for various gastrointestinal cell types that are important for modulating gut functions through their interactions with enteric neurons, such as enteric glia, enteroendocrine cells (EECs), and macrophages.

Glia closely associate with neurons in the gut and outnumber them by at least fourfold to sixfold (Gabella, 1981). We review recent studies that have challenged the dogma on glial functions in the gut and revealed surprising sex differences in the glial regulation of intestinal motility. Next, we review advances in the biology of EECs, which are specialized sensory epithelial cells that mediate chemosensation and mechanosensation across the gut 


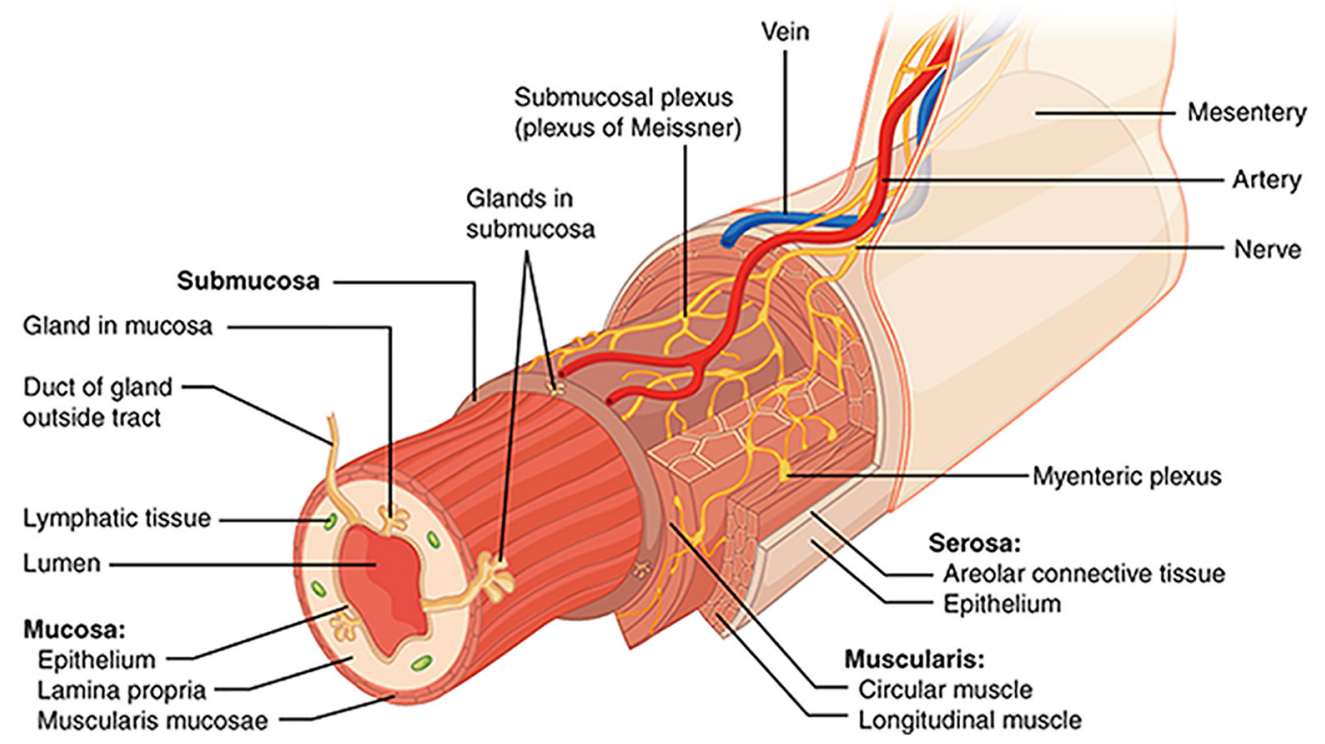

Figure 1. Organization of the enteric nervous system within the gut wall of the small intestine. The schematic illustrates the laminar organization of the bowel in three dimensions from the mesentery to the lumen. The two major plexuses of the ENS are the myenteric plexus, located between the circular and longitudinal muscle layers in the muscularis externa, and the submucosal plexus, located in the submucosa. Image was obtained from Wikimedia and reproduced under a Creative Commons Attribution-Share Alike 3.0 Unported license.

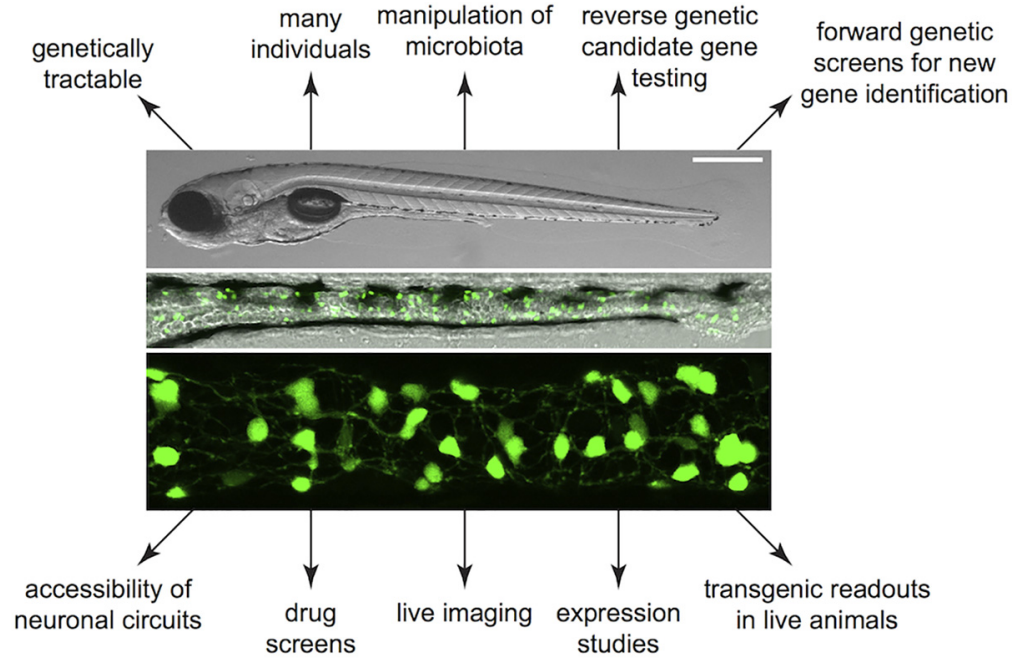

Figure 2. Zebrafish, a model system for investigating ENS development and function. Overview of distinguishing attributes of the zebrafish model system. Zebrafish larvae have an accessible ENS, labeled here with the phox2b:GFP transgenic line that marks enteric neurons (Taylor et al., 2016). Whole-mount side view of a 6 day post-fertilization zebrafish larvae in bright field (top), close-up image of the gut showing enteric neurons labeled with phox2b:GFP (middle), and phox2b:GFP ${ }^{+}$neurons and processes in higher magnification of the mid-gut (bottom). Scale bar, $500 \mu \mathrm{m}$.

epithelium. Understanding EEC biology is essential as they establish neurological-epithelial "synapses" with enteric afferent neurons and form a crucial part of the reflex microcircuits mediating intestinal motility. Finally, the gastrointestinal tract is also a primary site of cross talk among microbiota, the nervous system, and immune cells, such as macrophages. While macrophages are not formally part of enteric circuits, they closely interact with ENS cells to maintain and modulate their activity and hence help to regulate gut function. Here, we discuss how a subset of enteric macrophages regulates neural control of gut motility by secreting bone morphogenetic proteins (BMPs); and conversely how enteric neurons secrete signals that regulate macrophage homeostasis. This active cross talk between ENS and enteric macrophages is modulated by the presence and activity of the intestinal microbiota that signal to both macrophages and the ENS, and these in- teractions shift with aging to cause ENS degeneration. Along with reviewing these advances, we highlight important gaps in knowledge and opportunities in enteric neurobiology.

\section{Zebrafish as an emerging new model system for ENS research}

Zebrafish (Danio rerio) have long served as a model for studying developmental processes because of the following several unique attributes: they are genetically tractable; easy to maintain and breed; have large numbers of offspring that develop rapidly in an external environment; and are transparent, providing unparalleled opportunity for in vivo imaging (Fig. 2). In recent years, zebrafish have been used to study ENS development and function, as well as to evaluate candidate genes for human ENS diseases (Ganz, 2018). The zebrafish ENS is comparable in structure and neuronal complexity to the mammalian ENS, but it is much more accessible for imaging (Wallace et al., 2005; Ganz, 2018). Most genes are conserved between zebrafish and humans, and a set of conserved signaling pathways that regulate different aspects of ENS development has been identified in zebrafish and other vertebrate species (Wallace et al., 2005; Howe et al., 2013; Heanue et al., 2016a; Ganz, 2018). Thus, what we learn from zebrafish is directly applicable to mammalian ENS development and function.

A number of recent studies has successfully used morpholino antisense oligonucleotides, TALENs (transcription activator-like effector nucleases), or more recently CRISPR (clustered regularly interspaced short palindromic repeats)-based approaches in zebrafish to test the role of candidate genes in diverse human disorders, such as Hirschsprung disease, chronic intestinal pseudo-obstruction (CIPO), and autism spectrum disorder 
(Bernier et al., 2014; Bonora et al., 2015; Cheng et al., 2015; Heanue et al., 2016b; Gui et al., 2017). The suitability of zebrafish for performing high-throughput multiplexed CRISPR/Cas9 screens (Shah et al., 2015) has become even more important with the explosion of data from single-cell RNA sequencing and genome-wide association studies, which are rapidly expanding the list of candidate genes requiring functional testing. Zebrafish are also uniquely suited for studying host-environment interactions, and small-molecule screens in zebrafish have already uncovered a variety of nongenetic factors that can influence ENS development (Lake and Heuckeroth, 2013; Lake et al., 2013; Schill et al., 2016). Zebrafish are relatively easy to breed "germ free" and have been used to study the role of the ENS in bacterial community assembly, illustrating novel connections between host gut motility and microbial colonization (Wiles et al., 2016; Rolig et al., 2017). These studies benefited from the large number of offspring readily available and the ease of in vivo imaging in zebrafish, which made it feasible to assess bacterial colonization in combination with functional analyses of gut motility. This ease of imaging has been exploited to develop new programs to quantify different gut motility parameters that had not been captured previously with standard assays (Ganz et al., 2018).

Several gaps remain in the understanding of cellular and molecular pathways implicated in ENS development and maintenance, with neuronal circuit formation being a major one. The accessibility of the ENS in zebrafish provides a unique opportunity to dissect neuronal circuit formation in concert with intestinal function. The remarkable ability of zebrafish to regenerate different parts of their nervous system has provided important insights into the molecular factors that promote neural regeneration (Kizil et al., 2012). Recent studies have found similar regenerative capacities in the murine ENS (Kulkarni et al., 2017; De Vadder et al., 2018; Saha et al., 2018; Yarandi et al., 2018; and detailed below). The regenerative capability of the zebrafish ENS remains to be determined, but, if conserved, zebrafish could offer an ideal model system for studying adult enteric neurogenesis.

\section{Shifting paradigms of adult ENS maintenance}

While ENS development has been heavily studied in both health and disease (Newgreen and Young, 2002a,b; Young, 2008; Burns et al., 2009; Hao and Young, 2009; Bergner et al., 2014; Uesaka et al., 2016), there has been limited examination of how the ENS is maintained in the healthy adult gut. This is important because the ENS is routinely subjected to significant and continual mechanical stress (Gregersen and Kassab, 1996) and chemical insults from luminal contents (Sherman et al., 2015; Hyland and Cryan, 2016). In intestines from healthy adult animals, previous studies reported conflicting data on neuronal loss (Gabella, 1971, 1989; Gianino et al., 2003; Anitha et al., 2006, 2016) and detected no enteric neurogenesis from proliferating label-retaining precursor cells (Liu et al., 2009; Joseph et al., 2011). The expression of the transcription factor Sox10 marks the enteric neural precursor cells (ENPCs) that generate neurons during development, but in adult mice, Sox10 expression labels enteric glia. These cells show limited neurogenic capability in vivo, and that is restricted to repair after significant chemical injury (Laranjeira et al., 2011). These observations established the dogma that there is no ongoing neurogenesis in the healthy, mature intestine.

Recently, a report (Kulkarni et al., 2017) provided a paradigm shift in this understanding of the mechanisms of adult ENS maintenance. Using novel tools, such as two-photon in vivo microscopy, adult myenteric neurons were observed to be lost at a significant rate (Fig. 3). Despite this loss, neuronal numbers in myenteric ganglia were maintained, suggesting the presence of ongoing adult enteric neurogenesis. Using an updated method for labeling and detecting label-retaining thymidine analogs, proliferating ENPCs were observed to replace $~ 90 \%$ of adult myenteric neurons within 2 weeks (Fig. 3), thereby maintaining the enteric neuronal numbers (Kulkarni et al., 2017). Further, these ENPCs were found to express the neural precursor marker Nestin, but not Sox10, suggesting that Nestin and Sox10 mark distinct neurogenic and gliogenic populations, respectively, in adult mice. The study also provided evidence of robust plasticity in the neural circuitry, the biology of which is yet unknown. These findings are directly relevant to deciphering the etiology of gastrointestinal diseases. While ablation of the cell cycle regulator protein PTEN selectively in adult Nestin ${ }^{+}$cells caused enteric neuronal hyperplasia that mimicked the pathology of CIPO (Kulkarni et al., 2017), the ablation of PTEN selectively in adult enteric glia caused glial hyperplasia without altering neuronal number (Jonscher et al., 2018). These data suggest that the cells responsible for neuronal hyperplasia, which is prevalent in patients with long-term gut dysmotility (Kidane et al., 2015), might be Nestin ${ }^{+}$ENPCs.

In this new paradigm of ongoing and rapid enteric neuronal turnover, chronic ENS pathologies could be due to ENPC defects, resulting in altered neuronal numbers and/or dysfunctional neurons. Accumulating evidence suggests that luminal factors such 

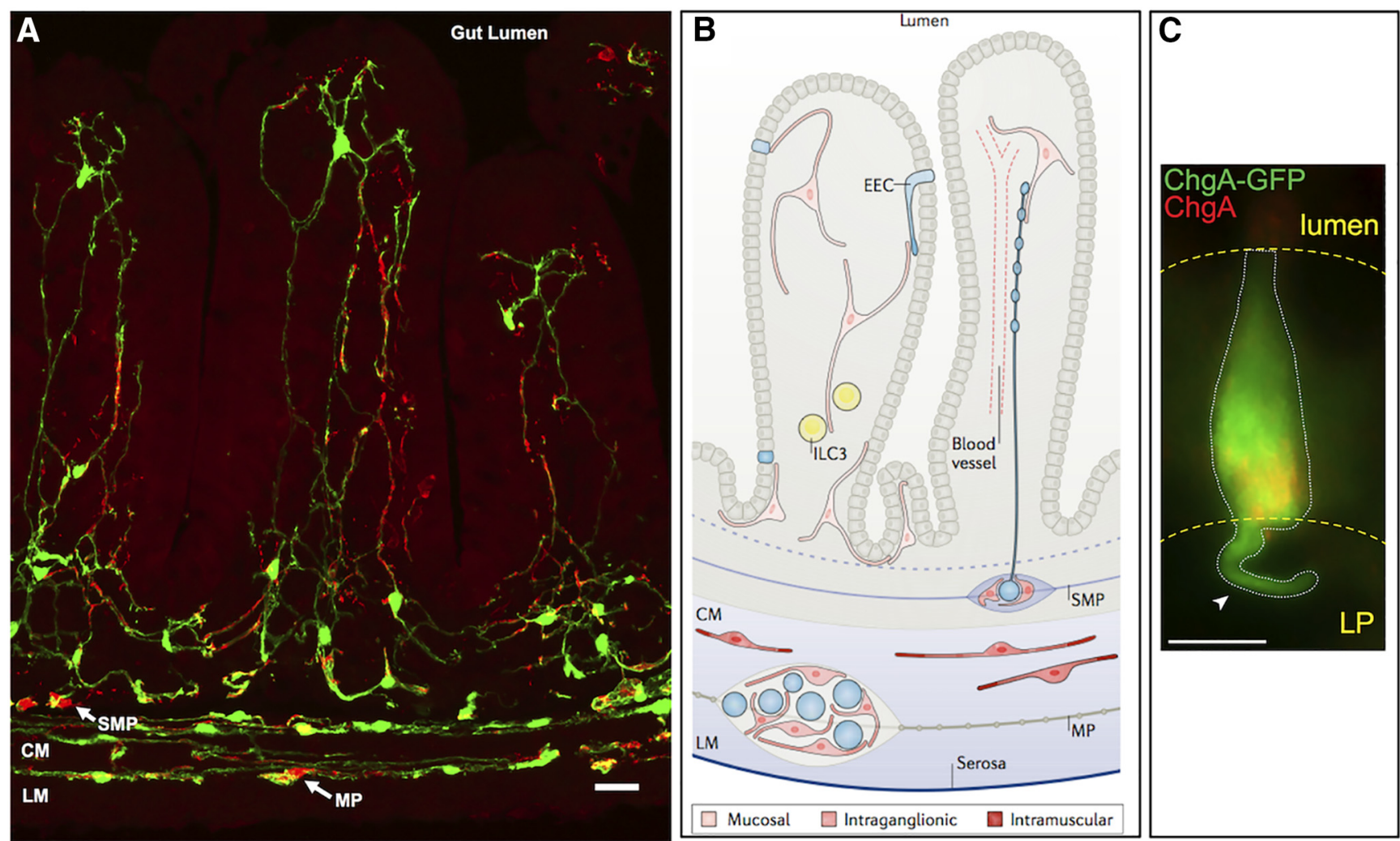

Figure 4. Glial diversity in the enteric nervous system. $\boldsymbol{A}$, Immunohistochemical staining of a cross section of small intestine from an adult PLP1-eGFP mouse in which green fluorescent protein (GFP) expression marks all enteric glia, illustrating the extensive glial network in the gut. Neurons are immunoreactive for PGP9.5 (red), and their soma are visible in the myenteric (MP) and submucosal (SMP) plexuses. The muscular externa consists of the longitudinal (LM) and circular (CM) muscle layers. Scale bar, $25 \mu \mathrm{m}$. $\boldsymbol{B}$, Schematic of enteric glial subpopulations and their interactions with other cell types. Mucosal glia are found in the lamina propria immediately underneath the epithelium and have been reported to interact with EECs, a subset of immune cells known as group 3 innate lymphoid cells (ILC3s; important for antimicrobial defense and maintaining tolerance to commensal microbiota), nerve fibers, and blood vessels. Intraganglionic glia are found within the enteric plexuses, closely apposing and partially ensheathing neurons (depicted as blue circles). Long, bipolar, intramuscular glia are found in the circular and longitudinal muscle layers, in close association with nerve fibers (data not shown) that innervate the smooth muscle. Image was reproduced with permission from SpringerNature (Rao and Gershon 2018). C, Enteroendocrine cell marked by GFP expression (green) driven by the chromogranin A (ChgA) promoter colocalizes with ChgA immunoreactivity (red). Yellow dashes indicate luminal and lamina propria (LP) surfaces. Arrowhead indicates neuropod. Scale bar, $10 \mu \mathrm{m}$.

as diet and microbiota influence ENPC behavior to cause gut pathologies (De Vadder et al., 2018; Saha et al., 2018; Shannon and Vanden Berghe, 2018; Yarandi et al., 2018). An in-depth understanding of the cellular and molecular pathways that regulate neurogenesis and subtype specification in the adult ENS needs to be determined so that the etiology of disorders such as achalasia, caused by a loss of a specific subset of enteric neurons, can be better defined (Mearin et al., 1993; Lui et al., 1997).

\section{Neuron-glia interactions in the ENS}

Our comprehension of glial biology in the ENS beyond its role in maintaining neurons has also evolved considerably over the past several years. Enteric glia were initially referred to as the Schwann cells of the gut because of a common developmental origin in the neural crest. But ultrastructural features (Gabella, 1971), along with the expression of molecular markers typically associated with astrocytes, such as GFAP and S100 $\beta$ (Jessen and Mirsky, 2005), led to these cells subsequently being characterized as "astroglia of the gut" (Gershon and Rothman, 1991). More recently, transcriptional profiling has challenged this long-standing characterization and suggested instead that enteric glia are most similar to myelinating glia, despite the lack of myelination in the ENS (Rao et al., 2015). It is possible that these conflicting characterizations of enteric glia reflect heterogeneity among enteric glia, with some types being more similar to astrocytes, while others resemble Schwann cells. Consistent with this possibility, enteric glia exhibit a variety of distinct morphologies and are located in markedly different microenvironments depending on whether they reside in enteric ganglia, along fiber tracts, or scattered in the smooth muscular or mucosal layers of the gut (Gulbransen and Sharkey, 2012; Fig. 4). Recent studies suggest that distinct subpopulations of enteric glia can be identified even within a single ganglion, based on molecular marker expression and activity profile (Boesmans et al., 2015; Zeisel et al., 2018). Despite this evident heterogeneity, clear functional classes of enteric glia have yet to be defined; determining these subtypes and understanding how they relate to other classes of glia in the nervous system remains an important task ahead.

While much has been learned about enteric glia over the past 20 years, their primary role in gut function remains incompletely understood. Initial studies based on genetic ablation of GFAPexpressing enteric glia suggested that they are essential for the maintenance of the intestinal epithelium, and that glial disruption compromises intestinal epithelial barrier integrity, causing fulminant intestinal inflammation (Bush et al., 1998; Aubé et al., 2006). Recent studies have questioned these findings, showing that functionally antagonizing enteric glia or ablating them in adult mice with a cell-autonomous toxin does not alter intestinal epithelial permeability in vitro or in vivo, or cause inflammation (Grubišić and Gulbransen, 2017; Rao et al., 2017). While enteric 
glia might not directly modulate the integrity of intercellular junctions in the epithelium, it is possible that they influence these junctions indirectly through their interactions with immune cells (Ibiza et al., 2016).

The role of glia in ENS-mediated behaviors has been characterized best in intestinal peristalsis, the coordinated propulsion of ingested nutrients and intestinal secretions from mouth to anus. While this motor behavior is thought to be the output of a seemingly simple microcircuit embedded in the gut wall, the peristaltic reflex is complex and incompletely understood. Moreover, it has a major role in important features of energy homeostasis such as blood glucose regulation. Enteric glia participate in bidirectional communication with enteric neurons to regulate motility (McClain et al., 2014; Rao et al., 2017), and this role is seemingly sex dependent, suggesting that much remains to be learned about neuron-glia interactions in even the most fundamental of ENSmediated behaviors.

\section{Enteric neuroepithelial interactions}

The intestinal epithelium represents one of the largest surfaces of the human body that is exposed to the outside environment and is continuously challenged by a variety of both exogenous and endogenous stimuli. Positioned at this luminal interface are EECs, specialized sensory epithelial cells that are scattered throughout the intestinal epithelium and are responsible for sensing this complex luminal environment (Engelstoft et al., 2013; Fig. 4). EECs assume a characteristic flask or pyramidal shape consisting of a narrow apical neck reaching to the luminal surface, a wide base housing large eosinophilic granules, and an axonal-like process extending laterally from the basolateral surface (Reimann et al., 2008; Bohórquez et al., 2011). Recently termed "neuropods," these neurofilament-containing processes can extend up to $70 \mu \mathrm{m}$ from the soma and possess secretory vesicles reminiscent of those found in neuronal synapses (Bohórquez et al., 2015).

At least a subset of EECs are electrically excitable and show spontaneous bursting activity in intestinal organoid cultures; these cultures have offered an exciting new approach to studying EEC activation by chemical and mechanical stimuli (Bellono et al., 2017; Alcaino et al., 2018). Sensory activity of EECs is mediated through their expression of cell surface receptors for nutrients, microbial byproducts, and host signaling molecules (Dyer et al., 2005; Samuel et al., 2008; Akiba et al., 2015; Bellono et al., 2017; Lund et al., 2018). A subclass of EECs called enterochromaffin cells (ECs) express voltage-gated $\mathrm{Na}^{+}, \mathrm{K}^{+}$, and $\mathrm{Ca}^{2+}$ channels (Bellono et al., 2017; Strege et al., 2017), which mediate chemical stimulus-dependent serotonin release, and Piezo2 channels, which mediate mechanical stimulus-dependent serotonin release (Wang et al., 2017; Alcaino et al., 2018). ECs are the major source of serotonin in the body, and EC-derived serotonin triggers the peristaltic reflex circuit upon mucosal deformation.

The mechanism of signal transduction from EECs to underlying neurons was thought to occur via paracrine or hormonal signaling. However, recent evidence using rabies virus tracing has demonstrated the presence of a potential synapse between a subpopulation of EECs and intestinal mucosal nerve fibers (Bohórquez et al., 2015). This is further supported by the presence of transcripts for synaptic machinery in EECs (Bohórquez et al., 2011; Bellono et al., 2017). These synaptic proteins have been found at the interface between $5 \mathrm{HT}_{3} \mathrm{R}^{+}$sensory afferent nerve fibers and juxtaposed ECs (Bellono et al., 2017). Complementing these anatomic studies, EC activation led to serotonin-dependent mucosal afferent nerve activation and increased mechanical sen- sitivity in an ex vivo gut-nerve preparation (Bellono et al., 2017). Recent optogenetic studies, furthermore, have found that stimulation of the colonic epithelium evokes the visceromotor response, a brainstem-mediated pain withdraw reflex triggered by noxious intestinal stimulation (Makadia et al., 2018). EEC-nerve communication may be bidirectional because EECs express postsynaptic proteins and can be activated by catecholamines, presumably from adjacent sympathetic nerve fibers (Bohórquez et al., 2015; Bellono et al., 2017).

Given the continual turnover of intestinal epithelial cells every few days, how EEC-mucosal nerve fiber synapses form remains an unanswered question. EECs migrate toward isolated trigeminal neurons in vitro and receive neuronal projections (Bohórquez et al., 2015), suggesting that dynamic synaptogenesis might occur in the mucosa. The average life span of most intestinal epithelial cells is only 5-7 d, but some EECs can persist for $>60 \mathrm{~d}$ (Bohórquez et al., 2015). It is possible that the EEC-nerve connection supports this observed increase in cellular longevity to favor synaptic stability. The biology of neurological-epithelial synapse formation and enteric sensory transduction are exciting areas for future work.

\section{Enteric neuroimmune interactions}

One of the most exciting developments in ENS biology has been in the realm of neuroimmune cross talk between enteric neurons and intestinal macrophages. Macrophages regulate organ development, postnatal homeostasis, and remodeling, and they induce the inflammatory response (Lavin et al., 2015). In the gut, muscularis macrophages (MMs) are a phenotypically and transcriptionally distinct population of macrophages that reside in the outer smooth muscle layer of the intestines (muscularis externa; Mikkelsen et al., 1985), where they are positioned along nerve fibers of the myenteric and the deep muscular plexuses and within the myenteric ganglia, adjacent to the cell bodies of enteric neurons (Fig. 5; Muller et al., 2014; Gabanyi et al., 2016). MMs in the healthy gut modulate intestinal motility via (1) secretion of BMP2, a growth factor that acts on enteric neurons (Muller et al., 2014); and (2) by maintaining ENS homeostasis, by phagocytosing adult neurons (Kulkarni et al., 2017). This is known to maintain ENS structure because an absence of macrophages in colony-stimulating factor 1 (CSF1)-deficient Csf $1^{\text {op/op }}$ mice results in increased myenteric neuronal numbers and a less organized ENS architecture (Muller et al., 2014). Whether MMs also regulate differentiation of ENPCs is unknown (Fig. 5).

The ENS-MM interaction might be involved in the pathophysiology of several diseases. Mucosal inflammation leads to functional changes of the ENS, causing neuronal loss and/or hyperinnervation, altered neurochemical phenotype, and neuronal hyperexcitability, all of which may persist long after inflammation is resolved. Development of plexitis, an inflammatory infiltrate of the neural plexuses in patients with inflammatory bowel disease suggests that MMs and their derivative inflammatory factors provide local inflammatory signals within the ENS, leading to neuronal loss. However, the exact mechanisms of this remain unknown (Brierley and Linden, 2014). In contrast to the role of diseased MMs in neurodegeneration, healthy MMs play a role in ENS regeneration by producing anti-inflammatory and neurotrophic growth factors that promote ENS regeneration after mucosal inflammation is resolved (Margolis et al., 2016). This suggests the presence of a complex context-dependent neurological-immune cross talk in health and disease.

Complementing the role of MMs in maintaining ENS homeostasis, the ENS regulates MM homeostasis and function. The vast 


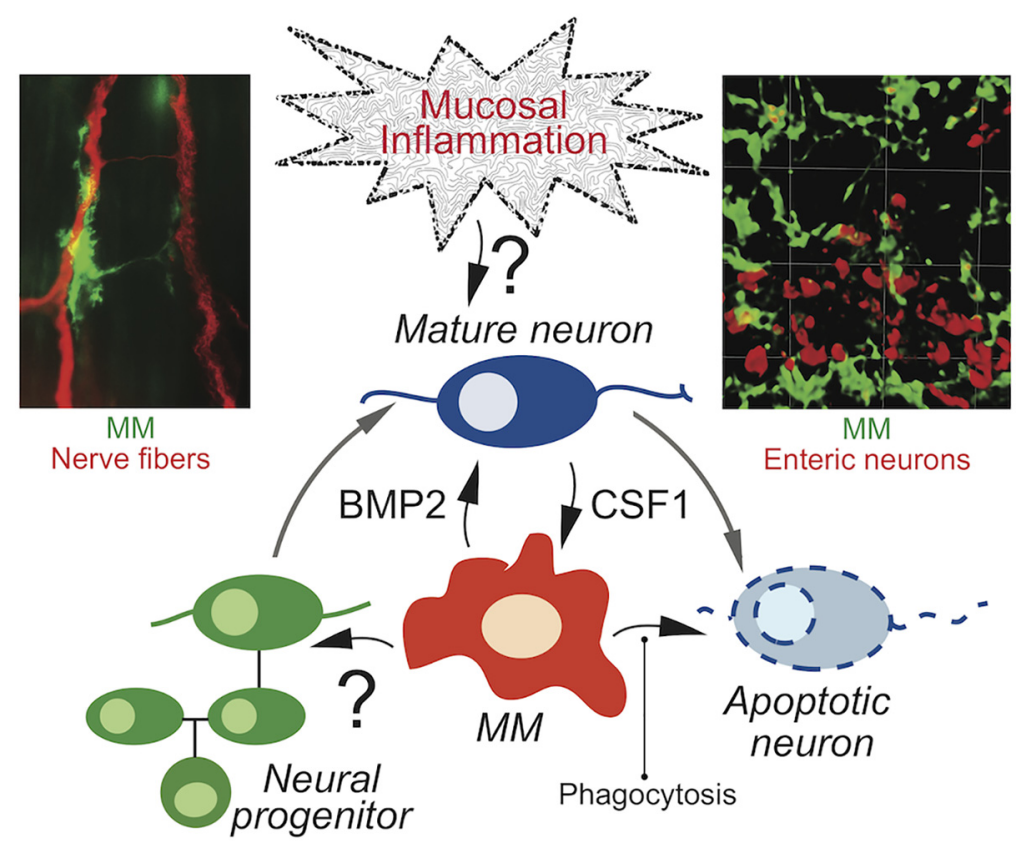

Figure 5. MMs are anatomically and functionally associated with the enteric nervous system. MMs are positioned along nerve fibers (top left) or within the enteric ganglia (top right) of the intestinal myenteric plexus. They control homeostasis and function of adult enteric neurons through the production of neurotropic growth factor BMP2 and phagocytosis of mature enteric neurons, and indirectly modulate neuromuscular function. Enteric neurons, in turn, control MM numbers through the production of macrophage-specific growth factor CSF1.

majority of murine MMs are derived from bone marrow progenitors, although a fraction of self-maintaining MMs has been described recently; all MMs are radiosensitive and are completely replaced by donor bone marrow cells after lethal irradiation followed by bone marrow transplantation (Muller et al., 2014; De Schepper et al., 2018). MM development is controlled by the presence of the cytokine CSF1, which is expressed by enteric neurons, suggesting the regulation of MM biology by the ENS. In addition, MM behavior is directly regulated by extrinsic neurons of the sympathetic nervous system (Gabanyi et al., 2016) and is indirectly regulated by the parasympathetic nervous system, likely through actions on enteric neurons, which then transduce signals to MMs (de Jonge et al., 2005; Cailotto et al., 2014; Matteoli et al., 2014). The physiological relevance of these signals in gastrointestinal health and disease, however, remains to be established. Furthermore, how the ENS controls MM function through neurotransmitter activity remains to be tested.

\section{Aging and enteric neuroinflammation}

Aging causes a decline in gastrointestinal neuromuscular function that contributes to a variety of common digestive disorders, including constipation, reflux, and fecal incontinence (Phillips et al., 2004; Camilleri et al., 2008; Saffrey, 2013). Age-related enteric neuronal loss and degeneration appear to play a role in these disorders (Camilleri et al., 2008; Saffrey, 2013). Studies in humans and animal models have described an age-associated decline in myenteric neurons in the small and large intestines (Saffrey, 2013). Although less studied, age-dependent loss of enteric glia has also been reported (Phillips et al., 2004). While there is evidence that oxidative stress, alterations in neurotrophic factors, and calcium dysregulation may contribute to these degenerative changes (Saffrey, 2013), recent discoveries have suggested that an aberration of enteric neurologicalimmune cross talk, which causes a chronic, low-grade inflammatory state known as "inflammaging" (Franceschi et al., 2007), plays a key role in the development of age-associated gut motility disorders (Becker et al., 2018a).

Increased inflammation is associated with an age-dependent rise in immune activation, apoptosis of enteric neurons, declining neuronal density within myenteric ganglia, and decreased intestinal transit (Becker et al., 2018a). Furthermore, ENPCs, resident stem cell populations that are key to maintaining ENS (reviewed in an earlier section), decline in number with age and inflammation (Molofsky et al., 2006; Becker et al., 2018a), suggesting that decreased neuronal density is partly due to an inflammaging-associated reduction in the neurogenic potential of the ENPC. Similarly, inflammatory processes, especially elevated interleukin-6 levels, increase enteric neuronal apoptosis, suggesting that inflammation creates a shortfall in neuronal numbers by increasing neuronal death while simultaneously reducing the rate of neuronal replacement (Becker et al., 2018a).

Multiple processes have been proposed as the cause for inflammaging, including increased production of proinflammatory cytokines due to a rise in senescent cells (Rodier and Campisi, 2011), alterations in the gut microbiota (Claesson et al., 2012; Thevaranjan et al., 2017), and changes to immune cells (Franceschi et al., 2007). Notably, several of these processes, such as the presence of senescent cells and altered MM behavior (whose "tone" tilts from an anti-inflammatory "M2" to proinflammatory "M1" state), have been detected in the ENS with aging (Jurk et al., 2012; Becker et al., 2018a). MMs from bone marrow chimeric mice, generated by transplanting bone marrow from old mice into lethally irradiated young recipients, demonstrate a loss of M2 phenotype similar to those from old mice (Becker et al., 2018a). Ongoing work suggests that the change in MM behavior with aging is associated with a significant change in intestinal microbiota composition, and both of these factors work in tandem to disrupt ENS structure and function and to cause intestinal dysmotility (Becker et al., 2018b). Recent work suggests the presence of a "triumvirate" of ENS, MM, and intestinal microbiota, whose cross talk is essential to regulate normal gut behavior. Given that there are limited therapeutic options for treating age-associated gut motility disorders, targeting functional interactions among this triumvirate to normalize age-associated aberrations in their cross talk could be a promising strategy for treating these disorders.

\section{Conclusion}

The recent advances in enteric neurobiology summarized above highlight the critical importance of continual cross talk among enteric neurons, glia, EEC, immune cells, and the many other component cells of the digestive tract in the regulation of gastrointestinal functions. Aberrations in the development and maintenance of the ENS, or communication between any of these cell types, could be associated with disease pathogenesis. This review provides a small glimpse of the complex cellular and molecular pathways involved in maintaining gut homeostasis and highlights some of the current gaps in knowledge. These gaps serve as exciting opportunities to improve our understanding of basic and translational enteric neurobiology. Any gains made are sure 
to advance CNS biology as well, given the bidirectional communication between the ENS and CNS along the gut-brain axis.

\section{References}

Akiba Y, Inoue T, Kaji I, Higashiyama M, Narimatsu K, Iwamoto K, Watanabe M, Guth PH, Engel E, Kuwahara A, Kaunitz JD (2015) Shortchain fatty acid sensing in rat duodenum. J Physiol 593:585-599. CrossRef Medline

Alcaino C, Knutson KR, Treichel AJ, Yildiz G, Strege PR, Linden DR, Li JH, Leiter AB, Szurszewski JH, Farrugia G, Beyder A (2018) A population of gut epithelial enterochromaffin cells is mechanosensitive and requires Piezo 2 to convert force into serotonin release. Proc Natl Acad Sci U S A 115:E7632-E7641. CrossRef Medline

Anitha M, Gondha C, Sutliff R, Parsadanian A, Mwangi S, Sitaraman SV, Srinivasan S (2006) GDNF rescues hyperglycemia-induced diabetic enteric neuropathy through activation of the PI3K/Akt pathway. J Clin Invest 116:344-356. CrossRef Medline

Anitha M, Reichardt F, Tabatabavakili S, Nezami BG, Chassaing B, Mwangi S, Vijay-Kumar M, Gewirtz A, Srinivasan S (2016) Intestinal dysbiosis contributes to the delayed gastrointestinal transit in high-fat diet fed mice. Cell Mol Gastroenterol Hepatol 2:328-339. CrossRef Medline

Aubé AC, Cabarrocas J, Bauer J, Philippe D, Aubert P, Doulay F, Liblau R, Galmiche JP, Neunlist M (2006) Changes in enteric neurone phenotype and intestinal functions in a transgenic mouse model of enteric glia disruption. Gut 55:630-637. CrossRef Medline

Becker L, Nguyen L, Gill J, Kulkarni S, Pasricha PJ, Habtezion A (2018a) Age-dependent shift in macrophage polarisation causes inflammationmediated degeneration of enteric nervous system. Gut 67:827-836. CrossRef Medline

Becker LS, Lee J-J, Bittinger K, Habtezion A (2018b) 913-Age-related changes in gut microbiota alter phenotype of muscularis macrophages and disrupt gastrointestinal motility. Gastroenterology 154 [Suppl 1]:S181. CrossRef

Bellono NW, Bayrer JR, Leitch DB, Castro J, Zhang C, O’Donnell TA, Brierley SM, Ingraham HA, Julius D (2017) Enterochromaffin cells are gut chemosensors that couple to sensory neural pathways. Cell 170:185-198.e16. CrossRef Medline

Bergner AJ, Stamp LA, Gonsalvez DG, Allison MB, Olson DP, Myers MG Jr, Anderson CR, Young HM (2014) Birthdating of myenteric neuron subtypes in the small intestine of the mouse. J Comp Neurol 522:514-527. CrossRef Medline

Bernier R, Golzio C, Xiong B, Stessman HA, Coe BP, Penn O, Witherspoon K, Gerdts J, Baker C, Vulto-van Silfhout AT, Schuurs-Hoeijmakers JH, Fichera M, Bosco P, Buono S, Alberti A, Failla P, Peeters H, Steyaert J, Vissers LELM, Francescatto L, et al (2014) Disruptive CHD8 mutations define a subtype of autism early in development. Cell 158:263-276. CrossRef Medline

Boesmans W, Lasrado R, Vanden Berghe P, Pachnis V (2015) Heterogeneity and phenotypic plasticity of glial cells in the mammalian enteric nervous system. Glia 63:229-241. CrossRef Medline

Bohórquez DV, Chandra R, Samsa LA, Vigna SR, Liddle RA (2011) Characterization of basal pseudopod-like processes in ileal and colonic PYY cells. J Mol Histol 42:3-13. CrossRef Medline

Bohórquez DV, Shahid RA, Erdmann A, Kreger AM, Wang Y, Calakos N, Wang F, Liddle RA (2015) Neuroepithelial circuit formed by innervation of sensory enteroendocrine cells. J Clin Invest 125:782-786. CrossRef Medline

Bonora E, Bianco F, Cordeddu L, Bamshad M, Francescatto L, Dowless D, Stanghellini V, Cogliandro RF, Lindberg G, Mungan Z, Cefle K, Ozcelik T, Palanduz S, Ozturk S, Gedikbasi A, Gori A, Pippucci T, Graziano C, Volta U, Caio G, et al (2015) Mutations in RAD21 disrupt regulation of APOB in patients with chronic intestinal pseudo-obstruction. Gastroenterology 148:771-782.e11. CrossRef Medline

Brierley SM, Linden DR (2014) Neuroplasticity and dysfunction after gastrointestinal inflammation. Nat Rev Gastroenterol Hepatol 11:611-627. CrossRef Medline

Burns AJ, Roberts RR, Bornstein JC, Young HM (2009) Development of the enteric nervous system and its role in intestinal motility during fetal and early postnatal stages. Semin Pediatr Surg 18:196-205. CrossRef Medline

Bush TG, Savidge TC, Freeman TC, Cox HJ, Campbell EA, Mucke L, Johnson MH, Sofroniew MV (1998) Fulminant jejuno-ileitis following ablation of enteric glia in adult transgenic mice. Cell 93:189-201. CrossRef Medline

Cailotto C, Gomez-Pinilla PJ, Costes LM, van der Vliet J, Di Giovangiulio M, Némethova A, Matteoli G, Boeckxstaens GE (2014) Neuro-anatomical evidence indicating indirect modulation of macrophages by vagal efferents in the intestine but not in the spleen. PLoS One 9:e87785. CrossRef Medline

Camilleri M, Cowen T, Koch TR (2008) Enteric neurodegeneration in ageing. Neurogastroenterol Motil 20:185-196. CrossRef Medline

Cheng WW, Tang CS, Gui HS, So MT, Lui VC, Tam PK, Garcia-Barcelo MM (2015) Depletion of the IKBKAP ortholog in zebrafish leads to hirschsprung disease-like phenotype. World J Gastroenterol 21:2040-2046. CrossRef Medline

Claesson MJ, Jeffery IB, Conde S, Power SE, O'Connor EM, Cusack S, Harris HM, Coakley M, Lakshminarayanan B, O’Sullivan O, Fitzgerald GF, Deane J, O'Connor M, Harnedy N, O’Connor K, O’Mahony D, van Sinderen D, Wallace M, Brennan L, Stanton C, et al (2012) Gut microbiota composition correlates with diet and health in the elderly. Nature 488 : 178-184. CrossRef Medline

de Jonge WJ, van der Zanden EP, The FO, Bijlsma MF, van Westerloo DJ, Bennink RJ, Berthoud HR, Uematsu S, Akira S, van den Wijngaard RM, Boeckxstaens GE (2005) Stimulation of the vagus nerve attenuates macrophage activation by activating the Jak2-STAT3 signaling pathway. Nat Immunol 6:844-851. CrossRef Medline

De Schepper S, Verheijden S, Aguilera-Lizarraga J, Viola MF, Boesmans W, Stakenborg N, Voytyuk I, Smidt I, Boeckx B, Dierckx de Casterle I, Baekelandt V, Dominguez Gonzalez E, Mack M, Depoortere I, De Strooper B, Sprangers B, Himmelreich U, Soenen S, Guilliams M, et al (2018) Selfmaintaining gut macrophages are essential for intestinal homeostasis. Cell. Advance online publication. Retrieved September 28, 2018. doi: 10.1016/j.cell.2018.07.048. Medline

De Vadder F, Grasset E, Mannerås Holm L, Karsenty G, Macpherson AJ, Olofsson LE, Bäckhed F (2018) Gut microbiota regulates maturation of the adult enteric nervous system via enteric serotonin networks. Proc Natl Acad Sci U S A 115:6458-6463. CrossRef Medline

Dyer J, Salmon KS, Zibrik L, Shirazi-Beechey SP (2005) Expression of sweet taste receptors of the T1R family in the intestinal tract and enteroendocrine cells. Biochem Soc Trans 33:302-305. CrossRef Medline

Engelstoft MS, Egerod KL, Lund ML, Schwartz TW (2013) Enteroendocrine cell types revisited. Curr Opin Pharmacol 13:912-921. CrossRef Medline

Franceschi C, Capri M, Monti D, Giunta S, Olivieri F, Sevini F, Panourgia MP, Invidia L, Celani L, Scurti M, Cevenini E, Castellani GC, Salvioli S (2007) Inflammaging and anti-inflammaging: a systemic perspective on aging and longevity emerged from studies in humans. Mech Ageing Dev 128: 92-105. CrossRef Medline

Furness JB (2006) The enteric nervous system. Malden, MA: Blackwell.

Gabanyi I, Muller PA, Feighery L, Oliveira TY, Costa-Pinto FA, Mucida D (2016) Neuro-immune interactions drive tissue programming in intestinal macrophages. Cell 164:378-391. CrossRef Medline

Gabella G (1971) Neuron size and number in the myenteric plexus of the newborn and adult rat. J Anat 109:81-95. Medline

Gabella G (1981) Ultrastructure of the nerve plexuses of the mammalian intestine: the enteric glial cells. Neuroscience 6:425-436. CrossRef Medline

Gabella G (1989) Fall in the number of myenteric neurons in aging guinea pigs. Gastroenterology 96:1487-1493. CrossRef Medline

Ganz J (2018) Gut feelings: studying enteric nervous system development, function, and disease in the zebrafish model system. Dev Dyn 247:268 278. CrossRef Medline

Ganz J, Baker RP, Hamilton MK, Melancon E, Diba P, Eisen JS, Parthasarathy $\mathrm{R}$ (2018) Image velocimetry and spectral analysis enable quantitative characterization of larval zebrafish gut motility. Neurogastroenterol Motil 30:e13351. CrossRef Medline

Gershon MD, Rothman TP (1991) Enteric glia. Glia 4:195-204. CrossRef Medline

Gianino S, Grider JR, Cresswell J, Enomoto H, Heuckeroth RO (2003) GDNF availability determines enteric neuron number by controlling precursor proliferation. Development 130:2187-2198. CrossRef Medline

Gregersen H, Kassab G (1996) Biomechanics of the gastrointestinal tract. Neurogastroenterol Motil 8:277-297. CrossRef Medline

Grubišić V, Gulbransen BD (2017) Enteric glia: the most alimentary of all glia. J Physiol 595:557-570. CrossRef Medline 
Gui H, Schriemer D, Cheng WW, Chauhan RK, Antiňolo G, Berrios C, Bleda M, Brooks AS, Brouwer RW, Burns AJ, Cherny SS, Dopazo J, Eggen BJ, Griseri P, Jalloh B, Le TL, Lui VC, Luzón-Toro B, Matera I, Ngan ES, et al (2017) Whole exome sequencing coupled with unbiased functional analysis reveals new Hirschsprung disease genes. Genome Biol 18:48. CrossRef Medline

Gulbransen BD, Sharkey KA (2012) Novel functional roles for enteric glia in the gastrointestinal tract. Nat Rev Gastroenterol Hepatol 9:625-632. CrossRef Medline

Hao MM, Young HM (2009) Development of enteric neuron diversity. J Cell Mol Med 13:1193-1210. CrossRef Medline

Heanue TA, Boesmans W, Bell DM, Kawakami K, Vanden Berghe P, Pachnis V (2016a) A novel zebrafish ret heterozygous model of Hirschsprung disease identifies a functional role for mapk 10 as a modifier of enteric nervous system phenotype severity. PLoS Genet 12:e1006439. CrossRef Medline

Heanue TA, Shepherd IT, Burns AJ (2016b) Enteric nervous system development in avian and zebrafish models. Dev Biol 417:129-138. CrossRef Medline

Howe K, Clark MD, Torroja CF, Torrance J, Berthelot C, Muffato M, Collins JE, Humphray S, McLaren K, Matthews L, McLaren S, Sealy I, Caccamo M, Churcher C, Scott C, Barrett JC, Koch R, Rauch GJ, White S, Chow W, et al (2013) The zebrafish reference genome sequence and its relationship to the human genome. Nature 496:498-503. CrossRef Medline

Hyland NP, Cryan JF (2016) Microbe-host interactions: influence of the gut microbiota on the enteric nervous system. Dev Biol 417:182-187. CrossRef Medline

Ibiza S, García-Cassani B, Ribeiro H, Carvalho T, Almeida L, Marques R, Misic AM, Bartow-McKenney C, Larson DM, Pavan WJ, Eberl G, Grice EA, Veiga-Fernandes H (2016) Glial-cell-derived neuroregulators control type 3 innate lymphoid cells and gut defence. Nature 535:440-443. CrossRef Medline

Jessen KR, Mirsky R (2005) The origin and development of glial cells in peripheral nerves. Nat Rev Neurosci 6:671-682. CrossRef Medline

Jonscher R, Woods C, Belkind-Gerson J (2018) Mo1587-Conditional ablation of Pten in glia enhances adult enteric neurogenesis. Gastroenterology 154 [Suppl 1]:S-761. CrossRef

Joseph NM, He S, Quintana E, Kim YG, Núñez G, Morrison SJ (2011) Enteric glia are multipotent in culture but primarily form glia in the adult rodent gut. J Clin Invest 121:3398-3411. CrossRef Medline

Jurk D, Wang C, Miwa S, Maddick M, Korolchuk V, Tsolou A, Gonos ES, Thrasivoulou C, Saffrey MJ, Cameron K, von Zglinicki T (2012) Postmitotic neurons develop a p21-dependent senescence-like phenotype driven by a DNA damage response. Aging Cell 11:996-1004. CrossRef Medline

Kidane B, Lam J, Manji F, Gupta V, Chadi SA, Taylor BM (2015) Histological findings in resected bowel of motility-disordered patients. Am Surg 81:187-192. Medline

Kizil C, Kaslin J, Kroehne V, Brand M (2012) Adult neurogenesis and brain regeneration in zebrafish. Dev Neurobiol 72:429-461. CrossRef Medline

Kulkarni S, Micci MA, Leser J, Shin C, Tang SC, Fu YY, Liu L, Li Q, Saha M, Li C, Enikolopov G, Becker L, Rakhilin N, Anderson M, Shen X, Dong X, Butte MJ, Song H, Southard-Smith EM, Kapur RP, et al (2017) Adult enteric nervous system in health is maintained by a dynamic balance between neuronal apoptosis and neurogenesis. Proc Natl Acad Sci U S A 114:E3709-E3718. CrossRef Medline

Lake JI, Heuckeroth RO (2013) Enteric nervous system development: migration, differentiation, and disease. Am J Physiol Gastrointest Liver Physiol 305:G1-G24. CrossRef Medline

Lake JI, Tusheva OA, Graham BL, Heuckeroth RO (2013) Hirschsprunglike disease is exacerbated by reduced de novo GMP synthesis. J Clin Invest 123:4875-4887. CrossRef Medline

Laranjeira C, Sandgren K, Kessaris N, Richardson W, Potocnik A, Vanden Berghe P, Pachnis V (2011) Glial cells in the mouse enteric nervous system can undergo neurogenesis in response to injury. J Clin Invest 121:3412-3424. CrossRef Medline

Lasrado R, Boesmans W, Kleinjung J, Pin C, Bell D, Bhaw L, McCallum S, Zong H, Luo L, Clevers H, Vanden Berghe P, Pachnis V (2017) Lineagedependent spatial and functional organization of the mammalian enteric nervous system. Science 356:722-726. CrossRef Medline

Lavin Y, Mortha A, Rahman A, Merad M (2015) Regulation of macrophage development and function in peripheral tissues. Nat Rev Immunol 15: 731-744. CrossRef Medline

Liu MT, Kuan YH, Wang J, Hen R, Gershon MD (2009) 5-HT4 receptormediated neuroprotection and neurogenesis in the enteric nervous system of adult mice. J Neurosci 29:9683-9699. CrossRef Medline

Lui H, Vanderwinden JM, Ji P, De Laet MH (1997) Nitric oxide synthase distribution in the enteric nervous system of children with cardiac achalasia. Chin Med J (Engl) 110:358-361. Medline

Lund ML, Egerod KL, Engelstoft MS, Dmytriyeva O, Theodorsson E, Patel BA, Schwartz TW (2018) Enterochromaffin 5-HT cells-a major target for GLP-1 and gut microbial metabolites. Mol Metab 11:70-83. CrossRef Medline

Makadia PA, Najjar SA, Saloman JL, Adelman P, Feng B, Margiotta JF, Albers KM, Davis BM (2018) Optogenetic activation of colon epithelium of the mouse produces high-frequency bursting in extrinsic colon afferents and engages visceromotor responses. J Neurosci 38:5788-5798. CrossRef Medline

Margolis KG, Gershon MD, Bogunovic M (2016) Cellular organization of neuroimmune interactions in the gastrointestinal tract. Trends Immunol 37:487-501. CrossRef Medline

Matteoli G, Gomez-Pinilla PJ, Nemethova A, Di Giovangiulio M, Cailotto C, van Bree SH, Michel K, Tracey KJ, Schemann M, Boesmans W, Vanden Berghe P, Boeckxstaens GE (2014) A distinct vagal anti-inflammatory pathway modulates intestinal muscularis resident macrophages independent of the spleen. Gut 63:938-948. CrossRef Medline

McClain J, Grubišić V, Fried D, Gomez-Suarez RA, Leinninger GM, Sévigny J, Parpura V, Gulbransen BD (2014) Ca2 + responses in enteric glia are mediated by connexin- 43 hemichannels and modulate colonic transit in mice. Gastroenterology 146:497-507.e1. CrossRef Medline

Mearin F, Mourelle M, Guarner F, Salas A, Riveros-Moreno V, Moncada S, Malagelada JR (1993) Patients with achalasia lack nitric oxide synthase in the gastro-oesophageal junction. Eur J Clin Invest 23:724-728. CrossRef Medline

Mikkelsen HB, Thuneberg L, Rumessen JJ, Thorball N (1985) Macrophagelike cells in the muscularis externa of mouse small intestine. Anat Rec 213:77-86. CrossRef Medline

Molofsky AV, Slutsky SG, Joseph NM, He S, Pardal R, Krishnamurthy J, Sharpless NE, Morrison SJ (2006) Increasing p16INK4a expression decreases forebrain progenitors and neurogenesis during ageing. Nature 443:448-452. CrossRef Medline

Muller PA, Koscsó B, Rajani GM, Stevanovic K, Berres ML, Hashimoto D, Mortha A, Leboeuf M, Li XM, Mucida D, Stanley ER, Dahan S, Margolis KG, Gershon MD, Merad M, Bogunovic M (2014) Crosstalk between muscularis macrophages and enteric neurons regulates gastrointestinal motility. Cell 158:1210. CrossRef Medline

Newgreen D, Young HM (2002a) Enteric nervous system: development and developmental disturbances-part 1. Pediatr Dev Pathol 5:224-247. CrossRef Medline

Newgreen D, Young HM (2002b) Enteric nervous system: development and developmental disturbances-part 2. Pediatr Dev Pathol 5:329-349. CrossRef Medline

Phillips RJ, Kieffer EJ, Powley TL (2004) Loss of glia and neurons in the myenteric plexus of the aged Fischer 344 rat. Anat Embryol 209:19-30. CrossRef Medline

Rao M, Gershon MD (2018) Enteric nervous system development: what could possibly go wrong? Nat Rev Neurosci 19:552-565. CrossRef Medline

Rao M, Nelms BD, Dong L, Salinas-Rios V, Rutlin M, Gershon MD, Corfas G (2015) Enteric glia express proteolipid protein 1 and are a transcriptionally unique population of glia in the mammalian nervous system. Glia 63:2040-2057. CrossRef Medline

Rao M, Rastelli D, Dong L, Chiu S, Setlik W, Gershon MD, Corfas G (2017) Enteric glia regulate gastrointestinal motility but are not required for maintenance of the epithelium in mice. Gastroenterology 153:10681081.e7. CrossRef Medline

Reimann F, Habib AM, Tolhurst G, Parker HE, Rogers GJ, Gribble FM (2008) Glucose sensing in L cells: a primary cell study. Cell Metab 8:532539. CrossRef Medline

Rodier F, Campisi J (2011) Four faces of cellular senescence. J Cell Biol 192:547-556. CrossRef Medline

Rolig AS, Mittge EK, Ganz J, Troll JV, Melancon E, Wiles TJ, Alligood K, Stephens WZ, Eisen JS, Guillemin K (2017) The enteric nervous system 
promotes intestinal health by constraining microbiota composition. PLoS Biol 15:e2000689. CrossRef Medline

Saffrey MJ (2013) Cellular changes in the enteric nervous system during ageing. Dev Biol 382:344-355. CrossRef Medline

Saha M, Wang Z, Kulkarni S, Pasricha PJ (2018) 200-The effects of dietinduced obesity on myenteric neurogenesis, neural differentiation and motility in the adult small intestine. Gastroenterology 154 [Suppl 1]:S-54. CrossRef

Samuel BS, Shaito A, Motoike T, Rey FE, Backhed F, Manchester JK, Hammer RE, Williams SC, Crowley J, Yanagisawa M, Gordon JI (2008) Effects of the gut microbiota on host adiposity are modulated by the short-chain fatty-acid binding G protein-coupled receptor, Gpr41. Proc Natl Acad Sci U S A 105:16767-16772. CrossRef Medline

Schill EM, Lake JI, Tusheva OA, Nagy N, Bery SK, Foster L, Avetisyan M, Johnson SL, Stenson WF, Goldstein AM, Heuckeroth RO (2016) Ibuprofen slows migration and inhibits bowel colonization by enteric nervous system precursors in zebrafish, chick and mouse. Dev Biol 409:473488. CrossRef Medline

Shah AN, Davey CF, Whitebirch AC, Miller AC, Moens CB (2015) Rapid reverse genetic screening using CRISPR in zebrafish. Nat Methods 12: 535-540. CrossRef Medline

Shannon K, Vanden Berghe P (2018) The enteric nervous system in PD: gateway, bystander victim, or source of solutions. Cell Tissue Res 373: 313-326. CrossRef Medline

Sherman MP, Zaghouani H, Niklas V (2015) Gut microbiota, the immune system, and diet influence the neonatal gut-brain axis. Pediatr Res 77: 127-135. CrossRef Medline

Strege PR, Knutson K, Eggers SJ, Li JH, Wang F, Linden D, Szurszewski JH, Milescu L, Leiter AB, Farrugia G, Beyder A (2017) Sodium channel NaV1.3 is important for enterochromaffin cell excitability and serotonin release. Sci Rep 7:15650. CrossRef Medline

Taylor CR, Montagne WA, Eisen JS, Ganz J (2016) Molecular fingerprinting delineates progenitor populations in the developing zebrafish enteric nervous system. Dev Dyn 245:1081-1096. CrossRef Medline

Thevaranjan N, Puchta A, Schulz C, Naidoo A, Szamosi JC, Verschoor CP, Loukov D, Schenck LP, Jury J, Foley KP, Schertzer JD, Larche MJ, Davidson DJ, Verdú EF, Surette MG, Bowdish DME (2017) Age-associated microbial dysbiosis promotes intestinal permeability, systemic inflammation, and macrophage dysfunction. Cell Host Microbe 21:455-466.e4. CrossRef Medline

Uesaka T, Young HM, Pachnis V, Enomoto H (2016) Development of the intrinsic and extrinsic innervation of the gut. Dev Biol 417:158-167. CrossRef Medline

Wallace KN, Akhter S, Smith EM, Lorent K, Pack M (2005) Intestinal growth and differentiation in zebrafish. Mech Dev 122:157-173. CrossRef Medline

Wang F, Knutson K, Alcaino C, Linden DR, Gibbons SJ, Kashyap P, Grover M, Oeckler R, Gottlieb PA, Li HJ, Leiter AB, Farrugia G, Beyder A (2017) Mechanosensitive ion channel Piezo2 is important for enterochromaffin cell response to mechanical forces. J Physiol 595:79-91. CrossRef Medline

Wiles TJ, Jemielita M, Baker RP, Schlomann BH, Logan SL, Ganz J, Melancon E, Eisen JS, Guillemin K, Parthasarathy R (2016) Host gut motility promotes competitive exclusion within a model intestinal microbiota. PLoS Biol 14:e1002517. CrossRef Medline

Yarandi S, Kulkarni S, Saha M, Sears CL, Pasricha PJ (2018) 432-The gut microbiota maintains neurogenesis in the adult colon via Toll-like receptor $2 / 4$ signaling pathways expressed by nestin ${ }^{+}$enteric neural precursor cells. Gastroenterology 154 [Suppl 1]:S-97. CrossRef

Young HM (2008) Functional development of the enteric nervous systemfrom migration to motility. Neurogastroenterol Motil 20 [Suppl 1]:2031. CrossRef Medline

Zeisel A, Hochgerner H, Lönnerberg P, Johnsson A, Memic F, van der Zwan J, Häring M, Braun E, Borm LE, La Manno G, Codeluppi S, Furlan A, Lee K, Skene N, Harris KD, Hjerling-Leffler J, Arenas E, Ernfors P, Marklund U, Linnarsson S (2018) Molecular architecture of the mouse nervous system. Cell 174:999-1014.e22. CrossRef Medline 